\title{
Conhecimento e poder: reflexões sobre as relações entre academia e judiciário no Brasil ${ }^{*}$
}

\author{
Knowledge and power: reflections on the relations be- \\ tween academia and judiciary in Brazil
}

RAFAEl LAZZAROtTo Simioni Faculdade de Direito do Sul de Minas, FDSM e Universidade do Vale do Sapucaí, UNIVÁS Pouso Alegre, Minas Gerais, Brasil

Resumo Esta pesquisa pretende estabelecer uma reflexão crítica a respeito dos possíveis contornos da disputa pela ocupação dos espaços de produção de sentido do direito no Brasil, neste início de século XXI. O poder dos tribunais acerca da definição do que é direito vai muito além de uma questão de teorias ou paradigmas. Concursos públicos, ensino jurídico e a própria racionalidade da prática forense encontram-se hoje determinados, exclusivamente, pelo regime de verdade dos tribunais. Todavia, sinaliza-se o surgimento de um novo ator no mapa da geopolítica do campo jurídico: a academia. Partimos da hipótese de que tribunais, advocacia e academia constituem diferentes organizações, com distintos tipos de discurso, de racionalidade e de regimes de verdade sobre o direito, os quais se encontram sob tensão. Por meio de uma pesquisa empírica ancorada na análise da relação entre, de um lado, as referências discursivas presentes nos principais meios de comunicação de massa do direito e, de outro, as referências discursivas evidentes nos boletins e informativos de jurisprudência dos tribunais, infere-se, como resultado, que esse tipo de conflito, diferente do século XX, não é uma disputa de teorias, de matrizes disciplinares ou de paradigmas, mas sim uma relação de poder pela própria episteme do direito. Uma disputa pela apropriação do poder de dizer o que é e o que não é saber jurídico. Palavras-chave: Episteme. Academia. Judiciário. Advocacia. Poder. Discurso. 
Abstract This research establish a critical reflection on the possible contours of the dispute for the occupation of the spaces of production of sense of the Law in Brazil, in this XXI century. The power of the courts in defining what is Law goes far beyond a matter of theories or paradigms. The rationality of legal practices are today determined, exclusively, by the truth regime of the courts. However, we observe a new actor in the geopolitics maps of the legal field: the academy. We start from the hypothesis that courts, advocacy and academy constitute different organizations, with different types of discourse, rationality and truth regimes on the law. Through an empirical research based on the analysis of the relation between, on the one hand, the discursive references present in the mass media of the law and, on the other, the discursive references present in the medias of the courts, it is inferred, as a result, that this type of conflict, different from the XX century, is not a dispute of theories, disciplinary matrices or paradigms, but a relation of power by the epistemic statute of law. A dispute over the power to say what is and what is not legal knowledge.

Key-words: Episteme. Academy. Judiciary. Lawyers. Power. Speech.

\section{INTRODUÇÃO}

Esta pesquisa sinaliza o surgimento de um novo ator nos espaços de produção de sentido do direito: a academia. Tradicionalmente, a fala autorizada do direito no Brasil e seus diferentes regimes de verdade encontravam-se sob o domínio da tensão entre advocacia e magistratura. Atualmente, a magistratura exerce um domínio sem precedentes sobre a episteme do direito. Concursos públicos, prova da $\mathrm{OAB}$, ensino jurídico, conceitos, métodos, teorias, paradigmas e grande parte dos saberes jurídicos de hoje não são mais definidos, como foram no século $\mathrm{XX}$, pelas disputas entre advocacia e magistratura. Os tribunais ocupam, atualmente, a posição de centro de produção de sentido do direito. Diante da qual as demais instituições jurídicas preenchem posições periféricas.

Todavia, de modo diferente das disputas entre magistratura e advocacia do século XX, atualmente é possível observar uma transforma- 
ção importante nessa geopolítica da ocupação dos espaços de produção de sentido do direito: com a criação de concursos públicos e planos de carreira específicos para a docência jurídica no ensino superior, o pensamento acadêmico sobre o direito conquistou autonomia. E como tal, identidade. Hoje, o discurso acadêmico constitui uma referência de sentido distinta tanto do discurso dos tribunais, quanto das advocacias pública e privada. Situada na periferia do sistema, pretende-se sinalizar a academia como um novo e importante ator a disputar os espaços de produção de sentido do direito e os desenhos dessa possível geopolítica epistêmica do direito.

Para tanto, partimos das seguintes hipóteses: a) é possível identificar diferenças entre discursos acadêmicos, advocatícios e jurisdicionais, que permitem inferir a existência de diferentes racionalidades, diferentes modos de compreensão do direito e diferentes campos de produção de sentido do direito; b) é possível identificar nesses diferentes discursos os contornos de uma disputa pela episteme do direito, isto é, uma disputa que não acontece no nível das teorias, matrizes disciplinares ou paradigmas, mas sim uma relação de poder pelo domínio da episteme do direito, isto é, pela ocupação dos espaços simbólicos de determinação do sentido do direito.

Não se trata de uma discussão sobre quem define os critérios de validade de um saber jurídico. Mais profundo do que um debate acerca da apropriação política dos critérios de validade do conhecimento jurídico, a relação que hoje pode ser observada entre judiciário e academia é uma disputa pela episteme do direito, isto é, pela positividade do conhecimento jurídico, pelo campo de produção de sentido daquilo que se considera direito.

Estabelecendo-se como corte metodológico a observação empírica de meios de comunicação de massa do direito, torna-se possível identificar os diferentes tipos de discursos que circulam entre o centro e a periferia da comunicação jurídica. Entendemos por meios de comunicação de massa do direito os veículos de comunicação jurídica que trabalham com as características típicas da comunicação de massa, como os ensaios, opiniões, notícias polêmicas veiculadas nos sites Migalhas, 
Justificando, Conjur, Informativo da Ajufe, a seção de artigos publicados pela Amagis, bem como, por sua vez, os boletins informativos realizados pelas assessorias de comunicação dos tribunais.

Nessa base empírica de observação, podem ser identificados e analisados os diferentes discursos pela apropriação privada dos espaços jurídicos. Justamente por constituírem meios não científicos de comunicação, ali acontecem as disputas de um modo mais bruto, menos lapidado, menos dissimulado por trás dos disfarces da racionalidade, do método e da erudição científica. Tanto nos sites de atualidades jurídicas, quanto nos boletins informativos dos tribunais, podemos encontrar os desenhos institucionais, os movimentos políticos e os mapas epistêmicos que constituem o imaginário da cultura jurídica brasileira deste início de século.

Para serem alcançados esses resultados, esta pesquisa utilizará tanto conceitos originários do pensamento desconstrucionista da $d i$ fférence francesa, como as noções de arquivo, episteme, arqueologia, genealogia, singularidade e diferença (FOUCAULT, 1969), quanto distinções conceituais da sociologia de matriz sistêmica (LUHMANN, 1993), como é o caso das diferenciações entre centro e periferia, sistema e ambiente, organização e decisão. Importante referir também que falamos de discurso no sentido de um sistema histórico, que estabelece uma dupla referência entre identidade e diferença, entre unidade disciplinar e exclusão do diferente, entre pertencimento e marginalização.

\section{JuÍZES, ADVOGAdOS E PROFESSORES}

Niklas Luhmann nos legou, entre outras, uma importante contribuição: a noção de que a positividade do direito não está na norma jurídica, mas nas decisões vinculantes que validam as normas para se justificarem a si mesmas (LUHMANN, 1993, p. 38-39). A validade do direito, com efeito, depende do seu reconhecimento em uma decisão judicial. Antes desse reconhecimento, uma norma jurídica não quer dizer nada além de uma pretensão de validade em abstrato que ainda vai depender de uma certificação jurisdicional para um caso concreto. E isso significa que, na realidade, a positividade do direito está na decisão judicial. 
Por isso os tribunais são o sistema de organização que ocupa o centro do sistema jurídico e em cuja periferia se encontram as demais instituições jurídicas, como as advocacias públicas e privadas. Segundo Luhmann, a regra do non liquet produziu esse estado de coisas. Entretanto, o fato de os tribunais ocuparem o centro da produção de sentido do direito não significa, necessariamente, a existência de uma relação hierárquica entre centro e periferia. Entre centro e periferia há uma relação diferente de referências comunicativas, não uma relação hierárquica.

Dependendo do sistema de organização em que atuam os atores do direito, as suas referências comunicativas mudam. E, com elas, mudam-se os papéis. Um juiz, no fórum, é um ator da prestação jurisdicional. O mesmo juiz, na academia, é um ator do processo de ensino e aprendizagem ou da pesquisa. Um advogado, no escritório, é um ator da realização material do direito dos seus clientes. O mesmo advogado, em uma sala de aula ou em um projeto de pesquisa, é um ator do ensino e do questionamento crítico. Dependendo da organização na qual estamos inseridos assumimos não só diferentes papéis sociais, mas também diferentes estruturas de racionalidade, de comportamento, de postura, de diferentes perspectivas de sentido da realidade.

No século XX, quando as faculdades de direito eram caracterizadas predominantemente por advogados e juízes bem-sucedidos que davam aula, a academia não possuía um papel autônomo de discussão e de reflexão crítica a respeito do direito. Esse papel era realizado por organizações como a $\mathrm{OAB}$ e a Magistratura em geral. Os grandes pensadores do direito, da época, eram advogados privados ou públicos, magistrados, políticos-advogados, filósofos-advogados, enfim, não havia uma referência consistente à academia como uma profissão jurídica ou como um sistema de organização autônomo em relação a essas instituições tradicionais do mundo jurídico.

A partir da criação dos concursos públicos para carreiras docentes na área jurídica e, especialmente, a partir da possibilidade de se exercer uma carreira docente na área jurídica com autonomia em relação às demais instituições jurídicas, tornou-se possível, também, o desenvolvimento de um novo sistema de organização, na periferia do direito, que nós queremos 
chamar simplesmente de academia. Hoje, a academia é uma organização que, ao lado das advocacias públicas e privadas, também constitui um ator importante da periferia do direito, cujo centro são os tribunais.

Para demonstrar a autonomia dos discursos acadêmicos brasileiros sobre o direito, realizamos uma pesquisa empírica em 266 textos $^{1}$ publicados nos seguintes meios de comunicação de massa do direito: Migalhas, Justificando e Conjur, que são sites de notícias, ensaios e opiniões sobre o mundo do direito; bem como o Informativo da Ajufe (Associação dos Juízes Federais do Brasil) e a seção de artigos publicados pela Amagis (Associação dos Magistrados Mineiros). Partimos da pergunta a respeito de quem são os autores dos textos veiculados nesses meios de comunicação de massa. Quem são os profissionais que se encontram nessa batalha epistêmica acerca do direito brasileiro e como eles se comportam em termos de escolha dos seus alvos.

Dos 266 textos analisados, seis são de autoria de estudantes de graduação em direito, 50 são de acadêmicos (professores e pesquisadores vinculados a instituições de ensino superior), 60 são de membros da magistratura, 120 são da advocacia privada, 21 são da advocacia pública (Ministério Público, Defensoria Pública, procuradorias etc.), nove são de outros intelectuais (jornalistas, economistas, cientistas políticos, oficial escrevente).

O gráfico a seguir demonstra a relação entre a quantidade de publicações realizadas por membros da academia, compreendidos nessa categoria os professores e pesquisadores vinculados a instituições de ensino superior, e a distribuição dos seus alvos de crítica:

Diante da enorme quantidade de publicações, a pesquisa precisou traçar um corte metodológico no sentido de delimitar temporalmente os textos de sua base empírica de observação. Para manter o índice de amostragem válido e ao mesmo tempo interessante, estipulamos um equilíbrio entre a grande quantidade de textos de meios como o Conjur, Migalhas e Justificando e a quantidade menor de textos de meios como a Ajufe e a Amagis. A equivalência da amostragem foi encontrada na relação entre um mês de publicações para o Conjur, Migalhas e Justificando (março de 2016) e três anos para a Amagis e Ajufe (março de 2013 a março de 2016). Essa delimitação da amostragem permitiu o levantamento de uma média de 60 textos em cada um desses diferentes meios de comunicação de massa do direito. 


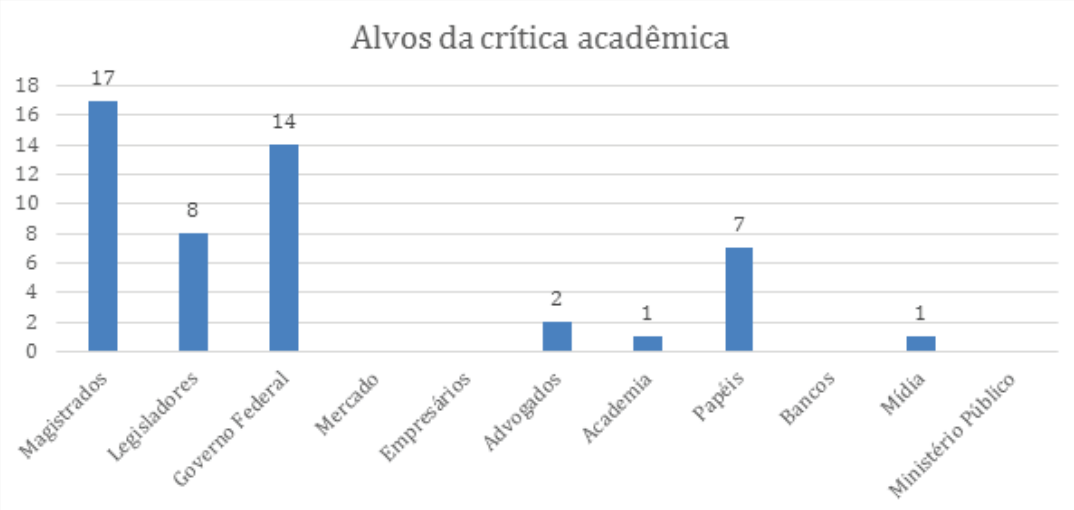

Das 266 publicações analisadas, 50 são de membros da academia, cujos alvos das críticas apresentam uma zona de sensibilidade maior ao Estado do que as demais categorias identificadas na pesquisa.

Isso significa, por inferência, que os discursos acadêmicos que transitam sobre os meios de comunicação de massa do direito têm direcionado suas críticas, predominantemente, ao Estado e, em especial, à magistratura. Isso é interessante porque demonstra certa identidade discursiva da academia como um novo ator no campo jurídico.

Já no campo da magistratura, a distribuição dos alvos de crítica revela outro cenário político:

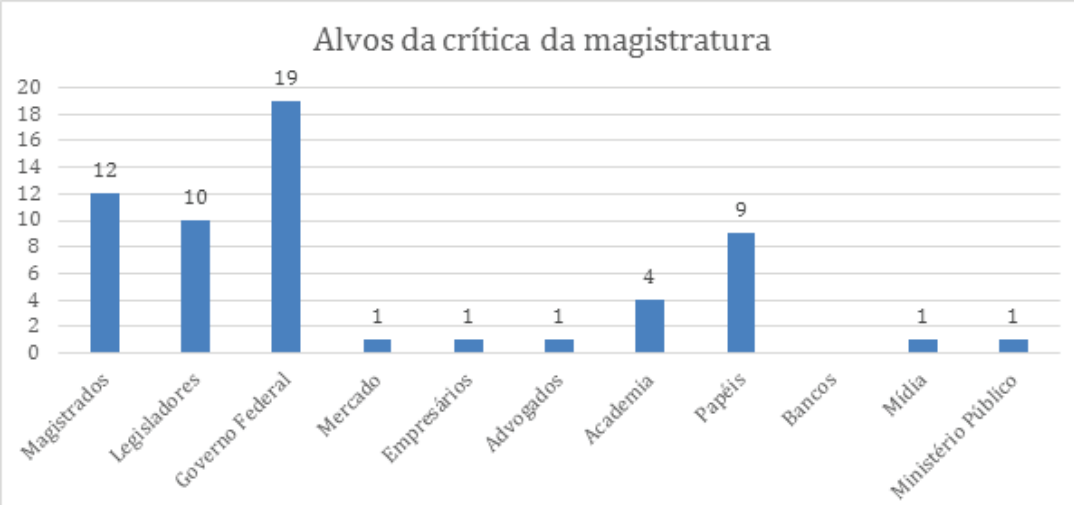


A magistratura publicou 60 textos dos 266 analisados, dos quais o principal alvo de crítica é o Governo Federal, seguido pelos próprios magistrados e depois os legisladores. Interessante observar essa recorrência do Estado como o principal alvo de crítica também dos magistrados, inclusive críticas à sua própria classe.

Chama a atenção também o fato de os magistrados possuírem uma distribuição maior dos alvos de crítica do que todas as demais categorias profissionais que publicaram alguma coisa nos meios de comunicação de massa analisados. Embora, como todas as outras profissões jurídicas, o Estado seja o Grande Centro das questões também para a magistratura, o seu discurso pontue também outras dimensões do campo jurídico.

Saindo da magistratura e entrando agora no campo da advocacia privada, observa-se um comportamento interessante na comunicação de massa do direito: a esmagadora maioria dos textos publicados por advogados privados são opiniões jurídicas sobre temas de especialidade do próprio advogado ou do seu escritório. Percebe-se uma intenção voltada ao mercado, à propaganda dos serviços realizados e não uma crítica, reflexão ou discussão convincente a respeito dos temas. Dos 266 textos, 120 são de autoria de membros da advocacia privada, distribuídos do seguinte modo:

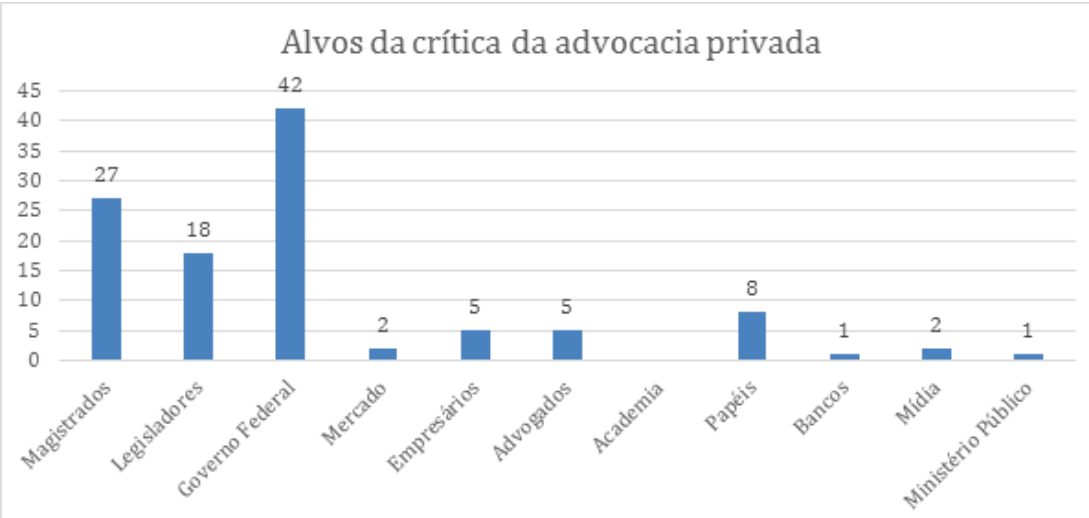


Como se observa no gráfico acima, também para os advogados privados o Estado e, em especial, o governo federal, é a grande fonte das questões jurídicas a serem debatidas. E tal como a distribuição das críticas pelos discursos da magistratura, também a advocacia cobre uma distribuição bem ampla de críticas ao mercado, aos empresários e também a si mesmos.

Já a advocacia pública não apresentou uma participação significativa nos meios de comunicação de massa do direito analisados. Dos 266 textos, apenas 21 são de autoria de membros das carreiras jurídicas públicas, como o Ministério Público, a Defensoria Pública, as procuradorias etc. A distribuição das críticas dos advogados públicos é a seguinte:

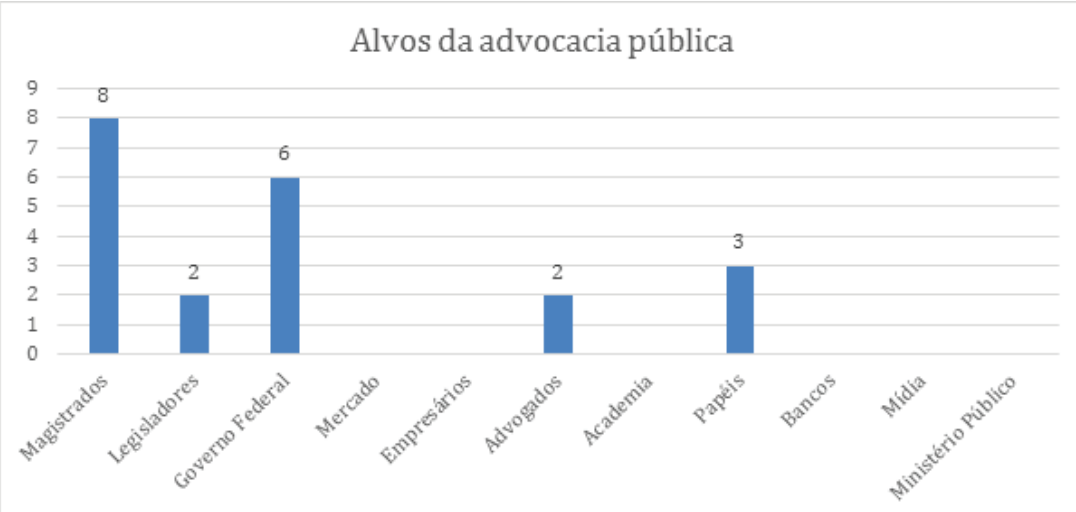

É recorrente o Estado como sendo o principal alvo da crítica, com destaque, segundo a sensibilidade midiática dos advogados públicos, aos magistrados. Infelizmente, os números são tão baixos que a margem de erro da amostragem torna-se muito alta para estabelecer conclusões. Entretanto, a hipótese permanece: advogados públicos e acadêmicos possuem uma distribuição de críticas similar entre si e diferente das críticas da magistratura e da advocacia privada, o que sugere a existência de diferenças discursivas, diferentes regimes de verdade entre as organizações da magistratura, das advocacias e da academia. Diferentes discursos que indicam diferentes papéis institucionais, racionalidades e 
finalidades acerca do direito. E isso significa a existência de autonomia e, portanto, de diferentes identidades entre essas diversas possibilidades de fala a respeito do direito.

\section{A EPisteme do direito e A FAla AUTORIZAda dA LEI}

Quando se observa a história do direito brasileiro, no século XX, pode-se ter a impressão de que há uma continuidade em direção ao progresso. Alguns tropeços, claro, mas no geral a história da experiência jurídica brasileira produz a impressão de que não existiram retrocessos jurídicos. Uma impressão de que a tendência do direito é um progressivo rumo à segurança jurídica, à objetividade, à racionalidade e à ordem. Uma direção percorrida rumo a maiores graus de legitimidade, alcançados pela progressiva constitucionalização do direito e dos ideais democráticos. Hoje, falamos até em princípios e isso constitui um grande progresso na experiência jurídica se comparada com as trajetórias históricas do século XX.

Entretanto, a história não possui essa linearidade. O direito brasileiro não seguiu uma tendência ao progresso, entendido como mais objetividade, segurança, racionalidade ou legitimidade. Também não se tornou mais sensível às exigências sociais do pluralismo jurídico, do realismo legal, do direito vivo ou de outras concepções sociológicas da prática jurídica. Há muitas descontinuidades na história do direito brasileiro. A ordem da episteme jurídica de hoje não é mais a mesma da do século XX. Sem dúvida, existe uma impressão de deriva entre uma ordem e outra. Uma impressão de que o neopositivismo de Hans Kelsen deriva do positivismo exegético do século XIX, ou da virada linguística lógica do Círculo de Viena, ou ainda da sociologia de Max Webber, do neokantismo de Marburgo. Há uma impressão de que o neoconstitucionalismo deriva do constitucionalismo. De que as teorias contemporâneas da democracia derivam das concepções gregas de política e não da república romana. Há uma impressão também de que o direito penal do inimigo deriva de uma ideologia burguesa do direito penal máximo e a criminologia crítica deriva de uma teoria crítico-marxista do crime. Ou 
de que a ponderação, a proporcionalidade e a razoabilidade derivam da adoção de um paradigma principiológico do direito, independentemente do que isso realmente significa.

Essas impressões e tantas outras que supomos em nossas práticas jurídicas são construções discursivas que decorrem de uma disputa pela episteme do direito, uma disputa pela positividade do saber jurídico. $\mathrm{Na}$ realidade, existem muitas descontinuidades, rupturas e até mesmo retrocessos na história jurídica brasileira do século XX. E não estamos falando simplesmente do óbvio retrocesso dos golpes militares dos anos de 1960 e 1970 à noção de democracia, da crença na criminalização como estratégia de controle e segregação social no final dos anos de 1990, dos golpes fundamentalistas à laicidade do direito nos últimos anos e tantas outras ilustrações. Descontinuidades, rupturas e retrocessos também acontecem, apesar da impressão superficial de deriva entre um campo jurídico e outro, quando a criação de um sentido novo se apresenta como deriva natural de outros conceitos ou princípios.

A questão está, portanto, na deriva. Porque ela naturaliza a história. Cria a impressão de que há conhecimentos que são descendentes biológicos de outros conhecimentos. Que possuem um DNA, uma essência, uma sublime verdade originária, cujo passado remoto já não precisamos mais recordar. A deriva marca a descendência entre os saberes. Ela regula a relação de proveniência dos saberes. Mas ela não tem nada de natural. Os saberes não são seres biológicos, que possuem um DNA, uma essência verdadeira, original, autêntica. Os saberes são construções de sentido submetidas a regras muito específicas de um legislador invisível. As regras que definem essa relação de deriva, que controlam a noção de descendência dos saberes, de pertencimento e de marginalização dos campos do conhecimento, queremos chamar, tomando uma sugestão de Foucault (1969, p. 249), de episteme.

Entendemos por episteme do direito o sistema de discursividade que controla a noção de deriva dos saberes jurídicos. É um campo que ordena, a partir de regras e princípios próprios, uma longa sequência de conhecimentos descendentes. É um espaço de domínio do saber. Uma episteme inclui dentro do seu campo os saberes que, segundo as suas regras, são 
dela descendentes, e exclui todos os demais como não saberes ou como não científicos ou como saberes marginais (FOUCAULT, 1966, p. 358). É um domínio que isola determinado campo do conhecimento. Ela controla as fronteiras do campo do saber. Define as condições de possibilidade de um campo de saber (FOUCAULT, 1966, p. 179).

A episteme é um conhecimento que seleciona, entre os diferentes conhecimentos, quais podem e quais não podem se reconhecer como pertencentes a ele. A episteme é o campo no qual os conhecimentos se reconhecem dentro de determinada relação de procedência e enraízam sua positividade, sua existência, sua identidade. E produzem, assim, história. A análise de uma episteme é uma análise das formações discursivas a respeito do saber. É uma arqueologia do saber, uma análise da positividade de um sistema de discursividade que controla o que pode ser dito e que deve ser silenciado, o que deve ser lembrado e o que deve ser esquecido (FOUCAULT, 1969, p. 249). A episteme controla o sistema da formação discursiva dos enunciados no campo do conhecimento.

\section{EPISTEME, TEORIA, MATRIZ DISCIPLINAR E PARADIGMA}

Todavia, para aproveitarmos a riqueza conceitual potencializada pela noção de episteme desenvolvida por Foucault (1966, p. 179, $358 ; 1969$, p. 249-250), precisamos avançar esse conceito no sentido de situá-lo em um campo analítico diferente das questões de teoria, de matriz disciplinar e de paradigma (KUHM 1996, p. 175). Queremos traçar uma distinção entre episteme, teoria, matriz disciplinar e paradigma, porque as estruturas discursivas presentes na comunicação jurídica brasileira contemporânea sinalizam a existência de uma disputa que não se encontra no nível das teorias, tampouco no nível das matrizes disciplinares, mas sim em um nível mais profundo, que também não é exatamente o nível dos paradigmas. Disputas de paradigmas são muito comuns nos diferentes campos dos discursos acadêmicos. Mas não são tão evidentes nas tensões entre academia e judiciário ou, como no século XX, nas pretensões de poder entre academia e advocacia. 
Se nós entendermos as disputas políticas entre academia e judiciário como disputas de paradigmas, estaremos apenas repetindo modelos de análise crítica desenhados a partir de experiências e de problemáticas europeias. Estaremos simplesmente importando explicações que já passaram pela fase do beneficiamento das empresas universitárias europeias. A disputa entre judiciário e academia que estamos sinalizando nessa investigação diz respeito a uma problemática presente em nossa realidade brasileira e não sabemos se ocorre também em outros lugares do mundo do mesmo modo como acontece aqui. Por isso não queremos simplesmente importar conceitos europeus ou norte-americanos para reproduzir uma versão exótica de problemas eurocêntricos. Queremos desenvolver esses conceitos a partir dos nossos próprios problemas.

Nessa perspectiva, precisamos delimitar o conceito de episteme proposto por Foucault (1966, p. 179, 358; 1969, p. 249-250), para que o entendamos não apenas como uma unidade analítica que marca a positividade dos saberes, mas também como uma unidade analítica que marca a condição prévia de possibilidade da positividade dos saberes. Nesse sentido, muito preciso do termo, queremos deslocar o conceito de episteme do plano do arquivo e sua arqueologia (FOUCAULT, 1969, p. 166), para os planos da deriva e da emergência, que são trabalhados por Foucault sob o nome de genealogia (2001, p. 136). Podemos fazer isso por meio de uma diferenciação entre episteme, teoria, matriz disciplinar e paradigma.

Uma episteme difere tanto das noções de teoria e de matriz disciplinar, quanto da noção de paradigma (KUHM, 1996, p. 175). De modo diferente de uma teoria, uma episteme não regula a validação das proposições científicas como verdadeiras ou falsas, justas ou injustas, corretas ou incorretas, racionais ou irracionais. A episteme regula a positividade dos saberes, a existência dos saberes dentro de determinado campo do conhecimento, não suas condições de validade. A episteme vem antes das teorias. Ela é condição da própria existência de uma teoria.

A apropriação e o controle de uma episteme jurídica, portanto, significam não apenas o controle das regras-teorias que validam os saberes jurídicos, não somente o controle das formas de produção de sentido 
do direito válido em determinada época e lugar. O controle da episteme jurídica significa também um controle prévio daquilo que pode ser considerado teoria jurídica em cada época e lugar. Em outras palavras, a disputa pela episteme é uma luta pelo poder de dizer o que é e o que não é uma teoria jurídica. É uma pretensão de controle daquilo que pode ser considerado regras de validação das proposições jurídicas e regras que não fazem parte daquilo que se considera conhecimento jurídico.

Uma episteme diferencia-se também da noção de matriz disciplinar porque, enquanto a episteme dita as regras que definem a positividade do conhecimento jurídico em cada época e lugar, uma matriz disciplinar constitui uma ordenação de elementos de várias espécies, a matriz, dentro de uma unidade comum, a disciplina. Uma matriz, portanto, é um esquema de organização de vários tipos de conhecimento. Um esquema que estabelece relações ordenadas entre diversos saberes. A reunião de distintas matrizes dentro de um campo específico de conhecimento chama-se disciplina. A matriz disciplinar, portanto, tem a ver com a organização das relações entre os saberes, enquanto que a episteme tem a ver com a dotação de existência a esses saberes. Uma matriz disciplinar regula o que é e o que não é objeto de estudo em determinada disciplina, enquanto que uma episteme, antes disso, regula o que é e o que não é objeto de conhecimento.

Controlar uma matriz disciplinar significa controlar as regras que definem os conhecimentos que devem ser estudados e os que não devem ser estudados, enquanto que controlar a episteme significa controlar as regras que definem a própria existência, a própria positividade daquilo que é e daquilo que não é conhecimento. Um governo pode interferir na matriz disciplinar das faculdades de direito, exigindo que se estude mais direito constitucional e menos direito negocial, como também pode decidir priorizar as matrizes disciplinares técnico-profissionalizantes do que as matrizes propedêutico-humanistas. Em qualquer hipótese, esse governo está optando entre um ou outro tipo de conhecimento. Está selecionando um tipo de conhecimento e excluindo outros, mas não está negando a existência dos conhecimentos excluídos. Prioriza uns, marginaliza outros, mas não nega a existência dos outros. 
Uma interferência na episteme, contudo, provoca um estado de coisas diferente: a imposi de uma episteme nstitucional eca um estado de coisas diferente: a imposio exigindo que se estude mais direito constitucional eção de uma episteme significa separar o que se considera conhecimento daquilo que não se considera conhecimento. $\mathrm{O}$ estudo de línguas, como latim e grego, que antes eram tidos tanto como conhecimento jurídico, quanto como disciplina na matriz curricular dos cursos jurídicos, hoje não apenas se encontra excluído de grande parte dos cursos de direito, como também se encontra afastado da própria episteme do saber jurídico contemporâneo. Latim e grego simplesmente não são mais saberes jurídicos. Diferente do direito romano, que se encontra excluído de grande parte das matrizes disciplinares das faculdades de direito do mundo ocidental, mas ainda faz parte da episteme jurídica tanto como teoria, quanto como história do direito.

A episteme, portanto, não deve ser confundida nem com uma teoria, tampouco com uma matriz disciplinar. Mas precisamos especificar mais a capacidade intelectiva do conceito de episteme desenvolvido por Foucault (1966, p. 179, 358; 1969, p. 249-250), por meio do estabelecimento de uma diferenciação em relação à noção de paradigma e o seu duplo sentido (KUHM 1996, p. 175): o paradigma no sentido de crenças, valores, técnicas, regras e métodos compartilhados pelos membros de uma comunidade científica previamente determinada, bem como, paradigma no sentido da generalização simbólica de uma parte dessas crenças, valores, técnicas, regras e métodos, como experiências exemplares para a solução de novos problemas.

Traçar uma distinção entre episteme e paradigma exige um maior grau de sofisticação, porque a riqueza, a profundidade e o alcance teórico desses dois conceitos fazem, entre eles, existir vários pontos em comum. Mas a disputa política que pode ser observada entre academia e judiciário, no Brasil, não pode ser suficientemente entendida por meio do conceito norte-americano de paradigma. Porque não há, aqui, propriamente, uma disputa sobre os critérios de validação do conhecimento jurídico. A tensão entre judiciário e academia, no Brasil, é mais profunda e sutil do que isso. Disputa-se pelo poder de dizer o que é co- 
nhecimento jurídico e não apenas quais são os critérios para a validação do conhecimento jurídico. A discussão acerca de quais são as melhores teorias, quais são os métodos mais adequados, quais são os conceitos funcionais mais úteis para a prática jurídica, sem dúvida, existe nos discursos acadêmicos. Mas essa discussão é apenas a superfície do embate político. No fundo, o que está em jogo é a ocupação dos espaços simbólicos que definem o que é e o que não é conhecimento jurídico no Brasil.

Há uma diferença, no Brasil, entre o poder de dizer o que se considera direito válido e o poder de dizer o que se considera direito existente. Há uma diferença entre o poder de dizer quais são os critérios de validade do direito que permitem a identificação de um direito válido e o poder de dizer o que se considera direito independentemente de considerações sobre a sua validade. Há uma diferença, portanto, entre o poder de escolha sobre diferentes visões do direito e o poder de dizer o direito. No âmbito dos discursos acadêmicos, a disputa pelas diferentes visões do direito pode ser empiricamente observada nas teses e dissertações, nos artigos e livros científicos, nas falas em congressos, simpósios, seminários, aulas. Os diálogos, as reflexões as críticas, os debates, enfim, a comunicação realizada no âmbito dos discursos científicos das academias são um tipo de comunicação que procura refletir acerca de quais são os melhores modos de se conceber o direito existente. ${ }^{2}$ Esses debates são conflitos de paradigmas: diferentes visões, diferentes imaginários possíveis sobre diferentes referentes simbólicos do direito.

No âmbito dos discursos do judiciário, por sua vez, disputas de paradigmas não fazem parte da agenda de questões dos tribunais. Ao contrário, na comunicação do judiciário é comum encontrar referência a conceitos paradigmáticos de modo acrítico, utilizados mais como argumentos de autoridade do que como argumentos sobre critérios de

\footnotetext{
2 A comprovação dessa proposição dependeria de uma pesquisa empírica que, todavia, não podemos realizar nesta oportunidade. Esperamos que se possa entender essa proposição em um sentido especulativo, ancorado na experiência intersubjetivamente compartilhada pela comunidade jurídica a respeito das temáticas e problemáticas dos discursos acadêmicos sobre o direito.
} 
validade para a fundamentação de determinado imaginário particular (RODRIGUEZ, 2017, p. 58).

Entre judiciário e academia, sem dúvida, há uma disputa superficial sobre diferentes visões paradigmáticas do direito. Mas no nível mais profundo, a disputa que ocorre não se limita à discussão a respeito dos paradigmas jurídicos mais adequados à experiência jurídica brasileira: ela invade a esfera do poder de dizer o direito, o poder de definição da positividade do direito.

Tal como os paradigmas, uma episteme também é uma visão de mundo que impõe regras de reconhecimento e postulados para um saber reconhecer-se como pertencente a determinado campo. Ela também é uma estrutura de pensamento da qual não se pode escapar. Mas de modo diferente dos paradigmas, a episteme não fala das condições de validação simbólica do conhecimento. Ela não determina os requisitos, métodos, procedimentos e scripts teóricos, compartilhados de modo generalizado, para validar um conhecimento como verdadeiro, correto ou justo. A episteme é um sistema de discursividade que controla a positividade do conhecimento, quer dizer, controla aquilo que existe como conhecimento em uma época ou lugar.

O conceito de episteme que estamos propondo, portanto, permite traçar uma distinção entre, de um lado, o reconhecimento da existência de um saber e, de outro, os critérios de validação simbólica de um conhecimento. A episteme regula o que pode ser reconhecido como saber, independentemente de ser um saber válido ou inválido, correto ou incorreto, verdadeiro ou falso. Enquanto que um paradigma, no sentido de Kuhm, regula as condições de validade dos saberes.

A disputa pelo que é saber válido é uma disputa de paradigmas. A disputa pelo que é saber é uma disputa pela episteme. A disputa pela apropriação dos critérios de validação do conhecimento científico é uma disputa de paradigmas. A disputa pela apropriação daquilo que se considera conhecimento é uma disputa epistêmica. A episteme não marca os limites do conhecimento válido ou verdadeiro, mas os limites da positividade do saber, os limites da existência do conhecimento como conhecimento científico (FOUCAULT, 1969, p. 250). Ela não questio- 
na a verdade, a correção ou a legitimidade desse conhecimento, mas sim a sua existência, a sua positividade. A episteme define as regras do jogo das coações e limitações que se impõem ao discurso em determinado momento, em determinada época.

\section{Tribunais E ACADEMIAS: A GEOPOLÍTICA DA FALA}

\section{AUTORIZADA DO DIREITO}

Entendemos por academia a rede de discursos realizados no âmbito das faculdades de direito. Entendemos por tribunais a rede de discursos feitos no campo da organização judiciária. Os sujeitos desses dois discursos também são diferentes. O sujeito do discurso acadêmico são professores, pesquisadores e estudantes da episteme jurídica. Enquanto que o sujeito do discurso judiciário são os magistrados membros do sistema de organização judiciária.

Obviamente, existem professores de direito que são juízes e juízes que são professores. Há também advogados, delegados de polícia, oficiais de justiça, que são, também, professores de direito. A questão é que existe uma mobilidade de papéis, comandada pelo sistema de organização que serve de referência discursiva em cada momento. $\mathrm{Na}$ sala de audiências, o juiz é juiz. Na sala de aula, o juiz é professor. No escritório, o advogado é advogado, na sala de aula, o advogado é professor. Quando observamos os espaços de não-lugar desses papéis profissionais, como é o caso dos sites de comunicação de massa do direito, essa mobilidade de papéis torna-se evidente: os discursos são diferentes de acordo não com a profissão do sujeito, mas conforme o contexto institucional, organizacional, no qual o ator organiza sua fala. No judiciário, o objetivo é a prestação jurisdicional. Na academia, é o ensino-aprendizagem e a pesquisa jurídica. Na advocacia, é a realização do direito material do cliente. São esses diferentes âmbitos de racionalidade que definem o papel que o ator está, a cada momento, fazendo parte. Como em nossas vidas privadas, não somos cientistas em nossa casa, não ficamos questionando e problematizando tudo o que nossos familiares pensam e fazem. Em casa, na família, exercemos outros pa- 
péis: de pai, de mãe, de filho, de irmão etc. Embora continuemos a ser juízes, advogados e professores.

Não importa saber-se quem é o sujeito humano desses dois diferentes tipos de discurso, porque não é o sujeito que o define e sim o sistema de organização do qual ele participa como membro (LUHMANN, 1998 , p. 826; 2000, p. 303). Ser membro de um tribunal significa a exigência de exercer determinado papel institucional previamente regulado pela própria história da organização (LUHMANN, 1993, p. 298). Do mesmo modo, ser membro de uma academia de ciência significa a exigência de exercer outro tipo de papel, mas que também é um papel previamente determinado pela história da organização universitária ou científica. Nesse sentido, o discurso dos membros dos tribunais, no âmbito dos tribunais, deve ser um discurso muito mais contido e delimitado do que o discurso dos membros das academias, no âmbito das academias. Isso porque os tribunais exercem uma posição de destaque sobre o poder de vinculação das decisões. Eles não são apenas a última palavra a respeito do que é direito, também são a única palavra que possui o poder de produzir vinculação aos destinatários da decisão jurídica.

Por sua vez, os discursos dos membros das academias não possuem o mesmo poder de vinculação, muito menos o poder de ser a última palavra sobre o direito. Ao contrário: o discurso acadêmico procura sempre a reflexão crítica, a autossuperação, a autorrefutação como condição do seu próprio aperfeiçoamento. Justamente por não possuir o poder de vinculação, o discurso acadêmico tem mais liberdade, tem a oportunidade de estabelecer relações inusitadas, inesperadas, surpreendentes. $\mathrm{O}$ discurso acadêmico pode e deve inovar, criar, propor a novidade, a originalidade, a crítica e a reflexão transformadora.

O discurso judiciário, ao contrário, deve guiar-se, tradicionalmente, pela conservação das tradições jurídicas exemplares. Não que ele não possa causar surpresa, polêmica e audiência para a mídia de massa. Mas não pode desempenhar um papel de discurso criativo original senão como reprodutor de um sentido já previsto originalmente no direito. A crítica e o frenesi pela novidade e pela transformação do conhecimento, que é muito estimulada nos discursos acadêmicos, é vis- 
ta como um perigo e fonte de preocupações nos discursos judiciários em geral. Quando um acadêmico propõe uma nova teoria, uma nova problemática ou uma nova solução para um ponto de vista tradicional, esse discurso surpreendente é aplaudido como crítico e inovador. Um mesmo discurso desses, no campo do judiciário, seria rechaçado como irresponsável, subjetivo, irracional e descomprometido com os ideais do Estado Democrático de Direito.

No judiciário, espera-se que o discurso estabeleça referências a precedentes, à legislação válida, à doutrina e à experiência jurídica exemplar, para que os jurisdicionados não sejam surpreendidos por uma interpretação inovadora e original do direito. $\mathrm{Na}$ academia se espera, ao contrário, que o discurso estabeleça referências às exigências sociais, históricas e antropológicas, que fundamentam o discurso em uma perspectiva sempre inovadora, surpreendente e original.

Um magistrado pode ser professor universitário e realizar discursos diferentes conforme o contexto institucional no qual ele se encontra como sujeito, como também um professor universitário, acostumado com a liberdade de expressão nos bancos acadêmicos, perceberá uma série de restrições a essa liberdade nas salas dos tribunais. Ao mesmo tempo em que um magistrado, confortavelmente inserido no jogo das repetições de precedentes sobre precedentes, poderá perceber uma desconcertante pressão, nos ambientes acadêmicos, das exigências de inovação, originalidade e questionamento crítico das práticas tradicionais.

Tratam-se, portanto, de dois tipos de discursos muito diferentes em suas estruturas. Não diferentes em termos formais, porque em ambos há equivalências estruturais (LORRAIN \& WHITE, 1971). Mas diferentes em termos materiais, porque os dois estabelecem referências comunicativas diferentes e praticamente contrárias entre si: o discurso acadêmico voltado à liberdade, à crítica e à inovação do conhecimento, enquanto o discurso judiciário, ao contrário, voltado às restrições da coerência, da consistência, da repetição e da conservação do conhecimento.

Há diferenças, portanto, entre o imaginário jurídico do ponto de vista dos sistemas de organização judiciária, que são os tribunais; e o imaginário jurídico do ponto de vista das academias. O direito é o mes- 
mo, a estrutura discursiva formal é similar, mas o sentido que se reconstrói na prática jurídica em um ou em outro campo é absolutamente diferente.

Simioni (2010, p. 27 e 93) analisou essas relações discursivas entre academia e judiciário, bem como, entre judiciário e advocacia. As academias procuram conceber o direito dentro de exigências de coerência, consistência e fundamentação, enquanto que os tribunais procuram entender o direito sob as exigências funcionais de solução dos casos na práxis forense. Os conceitos jurídicos, para as academias, precisam ser coerentes, consistentes e fundamentados. Enquanto que os mesmos conceitos jurídicos, para os tribunais, devem ser funcionais, aptos para resolver problemas práticos do cotidiano forense.

\section{Tensões discursivas SOBRE A EPISTEME do diREITo}

Essas diferenças entre academia e tribunais geram tensões discursivas. Os tribunais observam as exigências das academias como pretensões teóricas distantes da realidade prática do mundo forense. Enquanto que as academias enxergam as decisões judiciais como decisões problemáticas do ponto de vista das exigências de coerência, consistência e fundamentação. Do ponto de vista dos tribunais, as exigências da academia são entendidas como questões filosóficas interessantes, mas não importantes para a solução dos verdadeiros problemas práticos do cotidiano forense. E do ponto de vista das academias, as decisões jurídicas são entendidas como decisões cujos déficits de racionalidade são preocupantes para a estabilidade dos princípios do constitucionalismo e dos valores da democracia.

Essas diferenças produzem tensões que logo se deslocam também para outros campos da experiência jurídica. Elas ultrapassam a questão da decisão judicial e da condução dos processos. Abrangem também a questão da formação dos juízes, dos vencimentos, das prerrogativas, dos planos de carreira e de aposentadoria. Compreendem inclusive o tipo de teoria que os juízes devem ou não devem utilizar para a fundamentação de suas decisões judiciais. Tudo isso, sem dúvida, constitui 
uma pretensão de poder, potencialmente disparadora de uma série de conflitos que, em nome da ciência, as academias procuram exercer sobre os tribunais.

Por sua vez, os tribunais poderiam esperar das academias a formulação de novos conceitos jurídicos aptos a apresentar soluções funcionais para os novos problemas do cotidiano forense. Entretanto, a postura dos tribunais, por meio das referências discursivas utilizadas na formação de precedentes jurisdicionais, é a de referir-se apenas ou predominantemente à sua própria jurisprudência, como se os tribunais pudessem ignorar aquela série de pretensões críticas disparadas pela academia, a respeito do modo como eles decidem os casos práticos. Essa diferença é importante para revelar o tipo de disputa que decorre dessa tensão entre academia e tribunais. Porque enquanto as academias parecem gritar aos tribunais sem serem ouvidas, os tribunais ignoram esses gritos e não estabelecem outras pretensões à academia, senão apenas a clássica questão da formação dos novos profissionais do direito.

Há uma assimetria importante nessa tensão entre tribunais e academias: as academias exigem dos tribunais a adoção de certos paradigmas de decisão, enquanto que os tribunais demandam das academias apenas uma melhor formação dos bacharéis. ${ }^{3}$ Os tribunais seguem decidindo com base nas suas próprias decisões precedentes, independentemente do estardalhaço acadêmico que pode ser observado nos discursos presentes nos meios de comunicação das academias, como revistas ou blogs de opinião, revistas especializadas, congressos, simpósios, seminários, palestras, vídeos e outros tipos de comunicação produzidos no âmbito das estruturas discursivas acadêmicas. De um lado, o discurso acadêmico é bastante sensível a como os juízes decidem. De outro, o discurso judiciário é insensível às críticas e pretensões acadêmicas. Como se as academias não tivessem nada de útil para oferecer ao desenvolvimento da prática cotidiana da jurisdição. Como se as academias

3 A comprovação dessa afirmação depende de uma pesquisa empírica específica que, todavia, não podemos realizar nesta oportunidade. Esperamos que o leitor entenda isso como uma proposição especulativa baseada na experiência de observação de referências esparsas, casuais e informais dos tribunais em relação à academia e vice- versa. 
estivessem vivendo apenas sob um imaginário jurídico teórico, platônico, contemplativo, absolutamente distante das verdadeiras necessidades da prática jurisdicional.

Nunca a academia atacou tanto a racionalidade das decisões jurídicas dos tribunais no Brasil. Não temos precedentes, na história de nossa cultura jurídica brasileira, de uma relação tão potencialmente conflituosa como essa que pode ser observada nos discursos acadêmicos, especialmente os discursos de opinião política, que circulam nos meios de comunicação de massa do direito. Claro que Pontes de Miranda e outros pensadores importantes da cultura jurídica brasileira do século XX não poupavam críticas ao Supremo Tribunal Federal e demais tribunais da organização judiciária brasileira quando eles cometiam "erros" de aplicação do direito. As críticas duras desses pensadores, no entanto, eram críticas pontuais. Eram críticas que demonstravam erros na aplicação de um conceito ou de um instituto jurídico em determinado caso. De modo diferente dessas críticas do século XX, hoje pode-se observar críticas acadêmicas à própria racionalidade da decisão judicial, quando não críticas direcionadas à pessoa do juiz, à sua subjetividade, ao seu compromisso ideológico, ao seu humor e às suas prerrogativas, benefícios financeiros e estabilidade profissional.

A tensão discursiva entre academia e tribunais, na comunicação jurídica brasileira contemporânea, é diferente da tensão que acontecia no século XX entre juízes e advogados (CALAMANDREI, 1999; SIMIONI, 2010). Entre juízes e advogados, a tensão estava baseada na diferença entre as exigências de decidibilidade da prática jurisdicional, de um lado, e as exigências de satisfação do direito material dos clientes, de outro. Os juízes trabalhavam orientados à prestação jurisdicional eficiente sob a pressão do non liquet (LUHMANN, 1993, p. 308). Enquanto que os advogados trabalhavam orientados à satisfação dos interesses jurídicos dos seus clientes sob a pressão do mercado. Essas duas perspectivas sobre um mesmo direito geraram tensões interessantes no século XX. Mas elas não constituíram disputas pela ocupação dos espaços de produção de sentido do direito. Bem menos do que isso, essas tensões entre juízes e advogados constituíam disputas políticas mais li- 
gadas a interesses de classe do que a uma própria concepção de direito. Tratava-se de uma disputa de prerrogativas funcionais, cujos reflexos aparecem, por exemplo, na discussão da teoria do direito processual sobre conceber o conceito de ação/jurisdição como direito abstrato ou como direito concreto (SIMIONI, 2010, p. 93). A advocacia perdeu essa luta, por meio da afirmação do conceito de ação/jurisdição da tradição de Liebman, o qual permite, hoje, que se substitua o compromisso com o direito material por um compromisso instrumentalista com a tutela de pessoas, quer dizer, um compromisso com aquilo que os juízes pensam que é melhor para a satisfação do direito das pessoas, independente do que pensam os advogados.

Hoje, no entanto, a tensão entre tribunais e academia não tem a ver com uma disputa de prerrogativas, tampouco com uma disputa teórica ou paradigmática sobre os melhores modos de se conceber o direito. Mais sutil e profundamente do que isso, a tensão discursiva entre tribunais e academias se desenha no nível da episteme, isto é, no nível do jogo que regula o poder de dizer o que é e o que não é direito. No século $\mathrm{XX}$, entre juízes e advogados se discutiam prerrogativas, debatiam-se teorias, teses, entendimentos acerca dos critérios de validação do direito correto. Atualmente, entre tribunais e academias, discute-se, subliminarmente, quem comanda o que é e o que não é direito: discute-se quem é o dono da episteme do direito.

As academias afirmam essa discussão de modo explícito nas opiniões que circulam nos seus meios de comunicação de massa. Elas declaram expressamente o que deve e o que não deve ser direito válido, no nível das teorias e paradigmas jurídicos. Por sua vez, os tribunais afirmam essa discussão de modo explícito, porém negativo, nas referências discursivas utilizadas em seus precedentes jurisprudenciais. Nos precedentes, os tribunais afirmam essa discussão decidindo utilizar, como referências importantes da decisão, apenas outras decisões precedentes e não os discursos acadêmicos. Os tribunais negam os discursos acadêmicos em suas referências, por meio da afirmação, mediante o uso de referências exclusivas a precedentes, que não estão considerando os discursos acadêmicos como referências importantes para a solução e 
fundamentação das decisões jurisdicionais. Afirmam que estão dotando de realidade jurídica o sentido do direito criado e organizado pela prática jurisprudencial por eles realizada na história e, ao mesmo tempo, afirmam que não estão dotando de realidade jurídica o sentido do direito criado e organizado sob as exigências da coerência, da consistência e da fundamentação racional da prática acadêmica.

Isso significa uma transformação importante: no século XX, a tensão entre tribunais e advocacia era uma tensão que acontecia no nível da teoria. Não era uma tensão sobre a ocupação dos espaços simbólicos das disciplinas jurídicas, dos paradigmas e muito menos uma disputa pela episteme do direito. A tensão entre tribunais e academia, hoje, é diferente. É uma tensão discursiva que acontece entre o nível dos paradigmas e o nível da própria episteme do direito. Isso porque, para os tribunais, o que está em jogo é a apropriação dos espaços simbólicos de afirmação da positividade do direito, enquanto que, para as academias, o que está em disputa é a apropriação de espaços de afirmação de paradigmas, isto é, espaços de afirmação dos critérios de validade daquilo que se considera um saber jurídico verdadeiro, correto e adequado para a sua comunidade científica.

\section{A POSIÇÃo dA ACADEMIA No SISTEMA JURídico}

Ao concentrar suas referências discursivas à sua própria comunicação jurídica precedente, os tribunais afirmam-se como centro da produção de sentido do direito e colocam as academias na margem, na periferia da produção de sentido do direito. Por sua vez, as academias reconhecem explicitamente que os tribunais constituem esse centro. Elas não disputam, portanto, pela ocupação do lugar de centro ou de periferia do sistema jurídico.

Os discursos acadêmicos que nos referimos, que são veiculados na forma de opiniões nos meios de comunicação de massa do direito, constituem-se, no geral, como discursos periféricos à centralidade dos tribunais. E têm como temáticas, geralmente, os sujeitos juízes, as suas decisões, prerrogativas, plano de carreira, ou seja, colocam os tribunais 
como o ponto central do sistema. Mais central do que o próprio legislador, mais central do que poderia ser, por exemplo, as instituições do Ministério Público ou da advocacia são as que, antes da jurisdição, fazem os pedidos, apresentam as pretensões, delimitam os âmbitos de cognição dos problemas do mundo prático, como observou Assis (2012, p. 158) no campo da judicialização das políticas públicas de educação.

Esses discursos acadêmicos criticam, de um modo geral, a centralidade dos tribunais reconhecendo, paradoxalmente, essa centralidade. Ao mesmo tempo, os tribunais seguem decidindo, e ignorando tudo isso. Os tribunais não citam a proporcionalidade de Robert Alexy ou os princípios de moralidade política de Ronald Dworkin para satisfazer as exigências de coerência, consistência e racionalidade apontadas pelas academias. Eles citam Alexy e Dworkin em um mesmo parágrafo, como se o conceito de princípio de um não fosse contraditório ao conceito de princípio do outro. Eles utilizam, no geral, teorias jurídicas contemporâneas como discursos de autoridade, fato que demonstra, entre outras coisas, que as exigências acadêmicas não são importantes para os problemas práticos do mundo real dos tribunais.

\section{ConsideraÇões Finais}

Observamos nesta pesquisa um possível desenho do mapa geopolítico da fala autorizada do direito no Brasil. A partir da análise empírica dos diferentes discursos da magistratura, advocacias e academia, tornou-se possível observar a existência de diferentes perspectivas de sentido sobre a problemática do direito. E a partir da distinção proposta entre episteme e paradigma, tornou-se possível perceber a existência de um jogo de poder entre academia e judiciário pela própria episteme do saber jurídico.

Mais do que um conflito de paradigmas positivistas ou pós-positivistas, constitucionalistas ou neoconstitucionalistas, democráticos ou instrumentalistas, as relações que se estabelecem entre judiciário e academia no Brasil, hoje, ultrapassaram os limites das discussões pela validade do conhecimento jurídico, ultrapassaram a disputa de paradigmas. Sinalizamos a existência de uma relação de poder pelo controle 
do discurso epistêmico do direito: uma disputa não só pelo regime de verdade do direito, mas sobretudo pelo regime de existência daquilo que é e do que não é saber jurídico.

No centro, tribunais lançando, por meio de estratégias negativas de afirmação de referências discursivas, pretensões de poder fortíssimas pela apropriação exclusiva dos espaços simbólicos de produção de sentido do direito. Na periferia, academias disparando, por intermédio de estratégias positivas de afirmação de referências discursivas, contrapretensões de poder igualmente fortes pela ocupação dos espaços simbólicos de validação do direito.

Os tribunais, discursivamente fechados em seus próprios precedentes, observam as críticas da academia mediante a negação delas como referências discursivas importantes para a produção de sentido do direito em suas decisões. As academias, discursivamente abertas a várias referências políticas, econômicas, científicas e até mesmo morais, observam as decisões dos tribunais com bastante sensibilidade. A cada decisão polêmica do STF publicada, centenas de ensaios de opinião são publicados sobre ela nos meios de comunicação de massa do direito. A cada ensaio de opinião publicado, praticamente nenhuma referência sobre ele na jurisprudência de qualquer tribunal.

Os tribunais seguem decidindo com base nos seus próprios critérios, apesar das críticas da academia. E a academia segue criticando os déficits nos critérios das decisões judiciais, apesar do silêncio ou da insensibilidade dos tribunais a essas críticas. A tensão discursiva se encontra instaurada e pode potencializar importantes transformações recíprocas nessa relação.

Nas relações entre academia e judiciário, no Brasil, não se tratam de tensões teóricas sobre os critérios metodológicos de validade das decisões jurídicas. Não são as disputas de paradigmas sobre qual deve ser o imaginário mais adequado, correto ou verdadeiro do direito. Tratam-se, sim, de disputas pela apropriação da episteme do direito, pela apropriação das próprias regras que definem o que é e o que não é saber jurídico: uma disputa pela positividade, pelo domínio da existência do saber jurídico.

A doutrina jurídica, historicamente, exerceu um papel de crítica e de reflexão importantes para a prática das decisões jurídicas. A dife- 
rença é que, agora, a importância que os tribunais conferem à doutrina acadêmica já não é mais a mesma. Tanto para o judiciário, quanto para as academias, o discurso jurídico de referência não é a doutrina, mas sim a jurisprudência. A jurisprudência, que é o discurso do sujeito judiciário, conquistou um espaço epistêmico sem precedentes na história da cultura jurídica brasileira. Ela comanda os concursos públicos, a prova da $\mathrm{OAB}$, o ensino jurídico de massa e grande parte daquilo que se considera saber jurídico. Por sua vez, a doutrina, embora lida, constitui um discurso apenas eventualmente utilizado pela jurisprudência, com muito mais importância para as doutrinas proferidas por membros do judiciário do que por sujeitos de outras organizações.

Se essa leitura da realidade brasileira estiver correta, o arquivo do conhecimento jurídico já não se encontra mais nas academias, mas sim nos tribunais, na jurisprudência dos tribunais. $\mathrm{O}$ arquivo, no sentido de Foucault (1969, p. 166), é o sistema de discursividade que define o sentido da história. Ele guarda a existência do saber jurídico oficial, ao mesmo tempo em que coloca, utilizando-se uma metáfora de Derrida (1995), em "queima de arquivo" todo o restante do conhecimento jurídico marginal que, fora do arquivo, já não pode ser considerado mais como um saber jurídico: feudalismo epistêmico.

\section{REFERÊNCIAS}

ASSIS, Ana Elisa Spaolonzi Queiroz. Direito à educação e diálogo entre poderes, 2012, 259s. Tese (Doutorado em Educação) - Faculdade de Educação, UNICAMP, São Paulo, 2012.

CALAMANDREI, Pierro. Elogio dei Giudici Scritto da un Avvocato. Milano: Ponte alle Grazie, 1999.

DERRIDA, Jacques. Mal d'archive: une impression freudienne. Paris: Galilée, 1995.

FOUCAULT, Michel. Les mots et les choses: une archéologie des sciences humaines. Paris: Gallimard, 1966. 
FOUCAULT, Michel. L’archéologie du savoir. Paris: Gallimard, 1969. . Nietzsche, la généalogie, l' histoire. In: . Dits et Écrits II (1976-1988). Paris: Gallimard, 2001.

KUHM, Thomas S. The structure of scientific revolutions, 3. ed. Chicago: The University of Chicago Press, 1996.

LORRAIN, François; WHITE, Harrison. Structural equivalence of individuals in social networks. Journal of Mathematical Sociology, n. 1, p. 49-80, 1971.

LUHMANN, Niklas. Das Recht der Gesellschaft. Frankfurt am Main: Suhrkamp, 1993.

. Die Gesellschaft der Gesellschaft. Frankfurt am Main: Suhrkamp, 1998.

. Organisation und Entscheidung. Opladen/Wiesbaden: Westdeutscher Verlag GmbH, 2000.

RODRIGUEZ, José Rodrigo. Como decidem as Cortes? Para uma crítica do direito (brasileiro). Disponível em: https://www.uniceub.br/media/364804/ comodecidemascortes.pdf. Acesso em 10.07.2017.

SIMIONI, Rafael Lazzarotto. Direito processual e sociologia do processo: aproximações entre estrutura social e semântica do processo na perspectiva de Niklas Luhmann. Curitiba: Juruá, 2010.

\section{Sobre o autor}

Rafael Lazzarotto Simioni

Pós-Doutor em Filosofia e Teoria do Direito pela Universidade de Coimbra, Doutor em Direito Público pela UNISINOS, Mestre em Direito pela UCS, Professor do Programa de Mestrado em Direito da FDSM e do Programa de Mestrado em Bioética da UNIVÁS, Pesquisador-Líder do Grupo de Pesquisa Margens do Direito (PPGD/FDSM).

CV: http://lattes.cnpq.br/0651879354342863

E-mail: simioni2010@gmail.com

Submetido em: 22-7-2017

Aceito em: 28-11-2017 